\title{
Nutritional status and biomass of african mahogany seedlings grown with nutrient solution in the Northern Amazon*
}

\author{
Status nutricional e biomassa de mudas de mogno africano cultivadas com \\ solução nutritiva na Amazônia Setentrional
}

\author{
Oscar José Smiderle', Aline das Graças Souza ${ }^{\mathrm{II}}$, Edvan Alves Chagas ${ }^{\mathrm{I}}$, \\ Marcia Souza Alves ${ }^{\mathrm{III}}$, Paulo Renato de Oliveira Fagundes ${ }^{\text {IV }}$
}

\begin{abstract}
The objective of this work was to determine aspects about growth variables and dry mass partition of Khaya senegalensis seedlings and the nutrient absorption rate, depending on the seasons and mineral fertilization. The experimental design used was completely randomized, in a $2 \times 6$ factorial scheme. Two levels of nutrient solution factor (without addition) and six levels of time factor $(0 ; 60 ; 80 ; 100 ; 120$ and 140 days). Four replications were used, each one consisting of 10 seedlings. To evaluate the quality of the seedlings, morphological parameters, relationships and quality indexes were considered: Height $(\mathrm{H} ; \mathrm{cm})$; collar diameter $(\mathrm{CD} ; \mathrm{mm})$; shoot dry mass $\left(\mathrm{SDM}\right.$; g plant $\left.{ }^{-1}\right)$; dry root mass $\left(\mathrm{DRM}\right.$; g plant $\left.{ }^{-1}\right)$; total dry mass (TDM = SDW + RDW; g plant ${ }^{-1}$ ); shoot dry mass and root dry mass ratio (SDM/DRM); robustness index (RI $\left.=\mathrm{H} / \mathrm{DC} ; \mathrm{cm} \mathrm{mm}^{-1}\right)$; the Dickson quality index (DQI) and the accumulation of macronutrients in the shoots and root system. It is recommended to add solution for seedlings of Khaya senegalensis from 100 days after transplanting in the selected nursery in the Amazon. The maintenance of Khaya senegalensis seedlings with the use of the nutrient solution provides the best conditions for the use of macronutrients and obtaining suitable seedlings for the field in 140 days after transplanting in the selected nursery in Roraima
\end{abstract}

Keywords: Khaya senegalensis; Seedling production; Mineral nutrition

\section{Resumo}

O objetivo neste trabalho foi determinar aspectos sobre variáveis de crescimento e partição de massa seca das mudas de Khaya senegalensis, bem como a marcha de absorção de nutrientes, em função das épocas e adubação mineral. O delineamento experimental utilizado foi inteiramente casualizado, em esquema fatorial $2 \times 6$. Dois níveis do fator solução nutritiva (sem e com adição) e seis níveis para o fator período $(0 ; 60 ; 80 ; 100 ; 120$ e 140 dias). Foram utilizadas 4 repetições, sendo cada uma delas composta de 10 mudas. Para avaliação da qualidade das mudas, consideraram-se os parâmetros morfológicos, relações e índices de qualidade: altura da parte aérea $(\mathrm{H} ; \mathrm{cm})$; diâmetro do coleto $(\mathrm{DC} ; \mathrm{mm})$; massa seca da parte aérea (MSPA; g planta ${ }^{-1}$ ); massa seca da raiz (MSR; g planta $\left.{ }^{-1}\right)$; massa seca total (MST = MSPA + MSR; g planta ${ }^{-1}$ ); relação massa seca da parte aérea e massa seca da raiz (MSPA/MSR); índice de robustez (IR=H/ DC; $\mathrm{cm} \mathrm{mm}^{-1}$ ); e índice de qualidade de Dickson (IQD) e o acúmulo de macronutrientes na parte aérea e sistemaradicular. A adição de solução é recomendada para mudas de Khaya senegalensis a partir da época 100 dias após o transplantio em viveiro de telado na Amazônia setentrional. A manutenção das mudas de Khaya senegalensis com uso de solução nutritiva proporciona as melhores condições para o aproveitamento dos macronutrientes e permite obter mudas aptas para campo em 140 dias após o transplantio em viveiro de telado em Roraima.

Palavras-chave: Khaya senegalensis; Produção de mudas; Nutrição mineral

* Trabalho extraído da Tese do quinto Autor a ser apresentada no Programa de Pós-Graduação em Agronomia, Universidade Federal de Roraima Engenheiro Agrônomo, Dr., Pesquisador da Embrapa Roraima, Rod. BR 174, Km 08, Distrito Industrial, CEP 69301-970, Boa Vista (RR), Brasil. oscar.smiderle@embrapa.br (ORCID: 0000-0001-6692-1329) / edvan.chagas@embrapa.br (ORCID: 0000-0001-8604-7819)

II Bióloga, Dra., Professora da Faculdade Roraimense de Ensino Superior, Av. Presidente Juscelino Kubitscheck, 300 Bairro Canarinho, CEP 69306535, Boa Vista (RR), Brasil. alineufla@hotmail.com (ORCID: 0000-0001-8158-5933)

III Engenheira Florestal, Ma., Programa de Pós-Graduação em Agronomia, Universidade Federal de Roraima, BR 174, Km 12, Monte Cristo, CEP 69300-000, Boa Vista (RR), Brasil. marciasouza@hotmail.com (ORCID: 0000-0002-0623-601X)

IV Engenheiro Florestal, Me., Doutorando pelo Programa de Pós-Graduação em Agronomia, Universidade Federal de Roraima, BR 174, Km 12, Monte Cristo, CEP 69300-000, Boa Vista (RR), Brasil. pro.fagundes@yahoo.com.br (ORCID: 0000-0001-8348-6269) 


\section{Introduction}

The African Mahogany, originally from Africa, belongs to the genus Khaya and to the botanical family Meliaceae, with emphasis on four timber species of economic potential, Khaya ivorensis, Khaya grandifolia, Khaya anthotheca and Khaya senegalensis, described as African Mahoganies. Thus, these species have been suggested by the research to substitute the Brazilian mahogany (Swietenia macrophylla), due to its classification, use, competitiveness and high final value of this wood (SOUZA et al., 2020b). According to Souza et al. (2020b), the african mahogany plants grown in fertile soils, close to 20 years of age, can exhibit up to 35 meters in height and diameter up to 1.5 meter and from 8 to 16 stem without lateral ramifications. The species Khaya senegalensis, popularly known as African mahogany, has been the subject of recent research for presenting economic potential (provides wood of various noble uses) for the commercialization of its wood in the Brazilian and in the international markets (SMIDERLE et al., 2018).

In Brazil, the production of knowledge that guides optimal fertilization measures is essential with regard to the production of seedlings of exotic forest species with superior commercial characteristics. These seedlings can enhance the potential of success in implementing forest stands for timber purposes and can also guarantee the establishment and survival of programs for the recovery of degraded areas, since their growth and development will be directed from basic information to the balanced management of nutrients that promote the maximization of growth (CABREIRA et al., 2019).

This happens because the application of an adequate proportion of fertilizers, when adjusted for a given species, allows the maintenance of photosynthetic rates below the plant respiratory rates, inducing superior growth characteristics, such as robustness and dry mass production, both desired by the sector. Therefore, fertilization in a greenhouse is one of the most effective managements when the objective is to reduce the costs and waste of mineral fertilizers that occur in the nursery and post-planting phases (SMIDERLE; SOUZA, 2016).

Seedling quality varies between species, within species and between sites. Thus, the determination of these standards presupposes the choice of parameters and the definition of evaluation criteria. Morphological parameters are the most used in determining seedling quality indexes, having a more intuitive understanding by nurseries (AUCA et al., 2018). Among these parameters, the morphological ones, which include the height and diameter of the stem, are the most used ones in the definition of seedling quality indexes (DIONISIO et al., 2019).

During the seedling formation in the nursery, several factors influence the quality, growth and cost of the seedling production. Among the factors that influence the process of the forest seedling production sector and the morphological and physiological quality of the plants before final planting, the following ones stand out: substrate, substrate humidity, substrate porosity, temperature, shading, container, irrigation, seedling vigor, mineral fertilizer dose and seedling management in the nursery (MARQUES et al., 2018).

However, researchers have also shown the strong positive relationship between increased nutrient reserves in plants fertilized with nutrient solution and survival and vigor after transplanting the seedlings into the field (SHI et al., 2019), even in adverse edaphoclimatic conditions and limiting factors (AO et al., 2018), a reflex is attributed to the accumulation of nutrients in the nursery phase, which would represent an advantage to growth in the postplanting period.

In addition to this, the production of African mahogany seedlings does not yet have technical information on the accumulation of nutrients at each stage of development, as well as basic fertilization in the nursery, being performed many times empirically, using and applying equal doses, regardless of species or even the growth phase (MARQUES et al., 2018).

Research related to the march of nutrient absorption in Khaya senegalensis is of paramount importance, once it lacks results in the literature on mineral fertilization, which help in the adequate recommendation of mineral fertilizers. In scientific journals, in the last 20 years, no 
studies have been found on the march of accumulation of nutrients for this species.

Therefore, it is essential to carry out research and promote techniques to enable the production of commercial species of African mahogany that can be adapted to current planting systems, promoting greater productivity in commercial plantations. These studies can be an important basis for the decision making and for planning the production of seedlings and, or, forest implantation, with the scope of optimizing resources (SOUZA et al., 2020a).

Within this context, no present study aims to determine aspects about the growth and partition variables of the dry mass of the seedlings of Khaya senegalensis and the progress of nutrient absorption, depending on the seasons and mineral fertilization.

\section{Material and methods}

\section{Site Characterization}

The present work was carried out at 'Embrapa Roraima', in the forest seedling nursery, located in Boa Vista, Roraima (RR) state, Brazil, in the coordinates $\left(2^{\circ} 45^{\prime} 22^{\prime \prime}\right.$ north latitude, $60^{\circ} 43^{\prime} 55^{\prime \prime}$ west longitude and altitude of $80 \mathrm{~m}$ ), located on the banks of road BR-174, $\mathrm{km} 8$, Boa Vista, state of Roraima (Figure 1). The climate in the region is, according to Köppen, Am type (tropical monsoon climate) with average annual rainfall between $1700-2000 \mathrm{~mm}$ with average values of $365 \mathrm{~mm}$ and $26 \mathrm{~mm}$ for the months of greater (June) and less (February) precipitation, respectively. The averageannualtemperatureis $25.5^{\circ} \mathrm{C}$ (SMIDERLE et al., 2017).

Figure 1 - Location map of the experimental area, municipality of Boa Vista, Roraima state

Figura 1 - Mapa de localização da área experimental, município de Boa Vista, Roraima

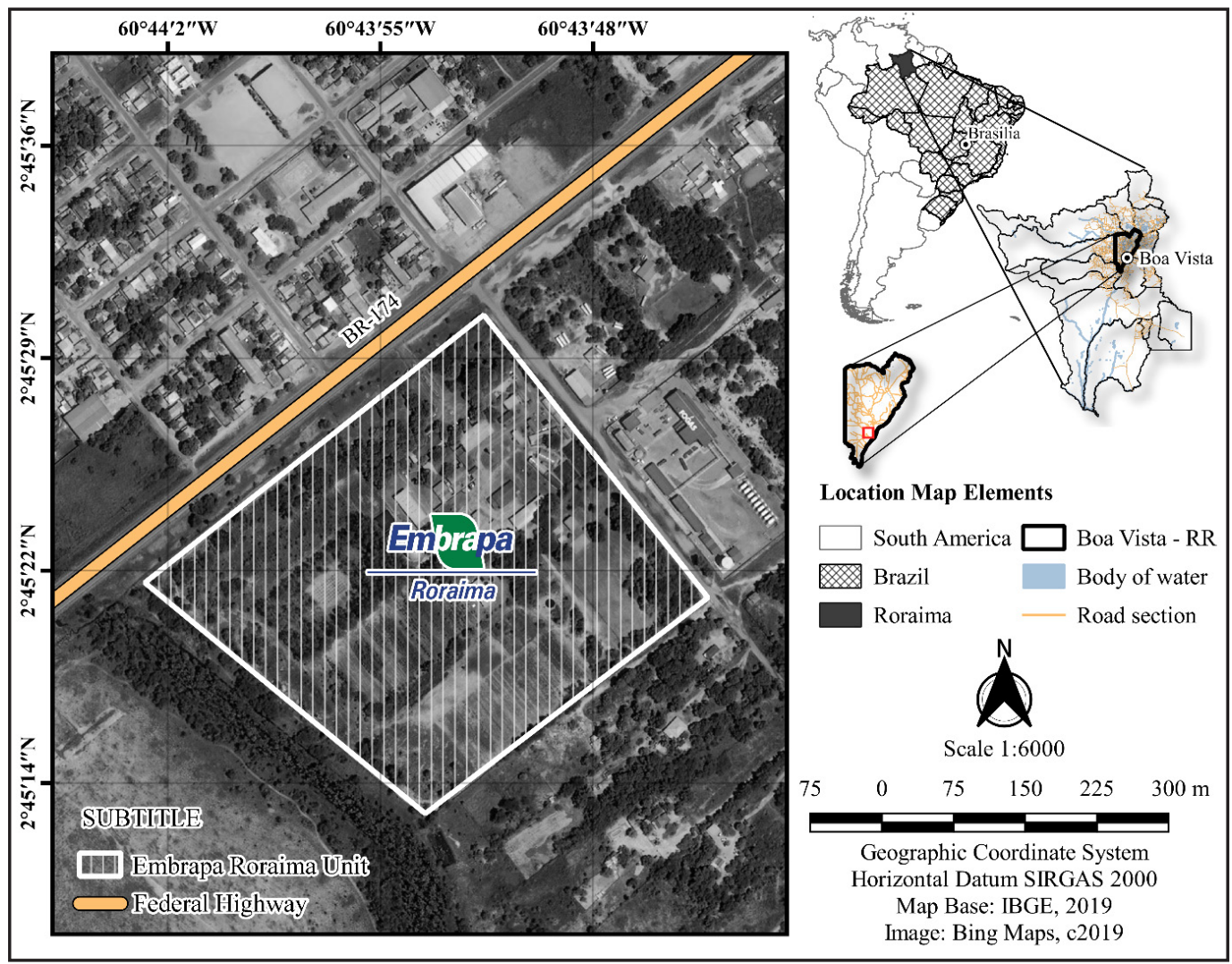

Source: Smiderle e Souza (2019)

Ci. Fl., Santa Maria, v. 30, n. 4, p. 958-970, out./dez. 2020 
The species used was Khaya senegalensis, from seeds obtained from matrices of the Brazilian Forest Institute (IBF). Seedling emergence started approximately 30 days after sowing. After that, as soon as the seedlings reached a uniform height of approximately $8.2 \mathrm{~cm}$, the transplanting was carried out, for which they were placed in polypropylene vases, these were filled with a thin layer of approximately $5 \mathrm{~cm}$ of pebble for better drainage and, completed with ORG substrate: OrganoAmazon ${ }^{\circledR}$ (Table 1).

Table 1 - Chemical composition, micronutrients and granulometryof the substrate (OrganoAmazon $^{\circledR}$ ) used in the growth of Khaya senegalensis

Tabela 1 - Composição química, micronutrientes e granulometria do substrato (OrganoAmazon $^{\oplus}$ ) usado no crescimento de Khaya senegalensis

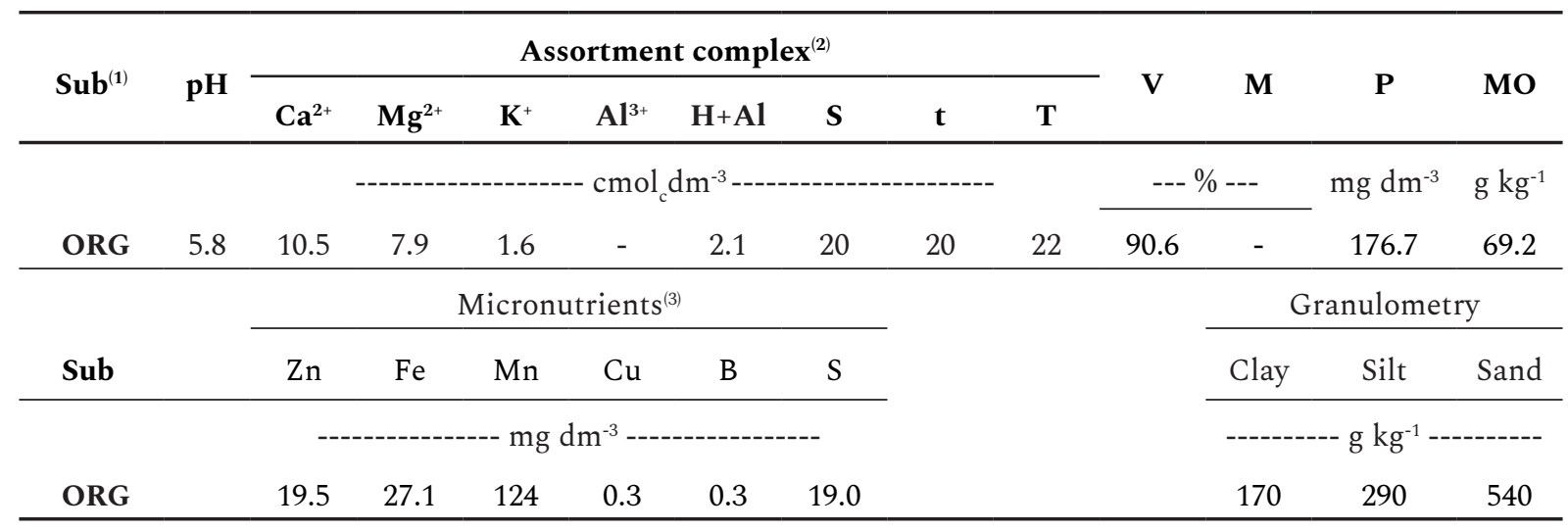

Source: Authors (2019)

Where: (1) ORG substrate: Organoamazon ${ }^{\circledR}$. (2) $\mathrm{pH}$ in water (1: 2.5); $\mathrm{Ca}^{2+}, \mathrm{Mg}^{2+}$ and $\mathrm{Al}^{3+}: \mathrm{KCl}^{1} \mathrm{~mol} \mathrm{~L}^{-1}$ extractor; $\mathrm{K}^{+}$ and P: mehlich ${ }^{-1}$ extractor; $\mathrm{H}+\mathrm{Al}$ : SMP extractor; M.O.: organic matter - oxidation $\mathrm{Na}^{2} \mathrm{Cr}_{2} \mathrm{O}_{7} 4 \mathrm{~N}+\mathrm{H}_{2} \mathrm{SO}_{4} 10 \mathrm{~N}$; S: sum of exchangeable bases; t: effective cation exchange capacity (CTC); T: CTC at pH 7.0; V: base saturation index; m: aluminum saturation index. (3) Zn, Fe, Mn and Cu: mehlich-1 extractor; B: hot water extractor; S: monocalcium phosphate extractor in acetic acid.

Subsequently, the seedlings were stored in a screened nursery with Sombrite ${ }^{\circledR} 50 \%$ and kept under sprinkler irrigation, in order to make a total of three daily irrigations of five minutes each. The seedlings received two waterings of $200 \mathrm{~mL}$ of the nutrient solution weekly (Table 2), according to the methodology proposed by Souza et al. (2015), at the end of the last irrigation, of the day to avoid leaching of nutrients.

Table 2 - Composition of the nutrient solution used in the production of Khaya senegalensis seedlings

Tabela 2 - Composição da solução nutritiva utilizada na produção de mudas de Khaya senegalensis

\begin{tabular}{|c|c|c|c|c|c|c|c|c|c|c|c|}
\hline Composition & $\mathrm{N}-\mathrm{NO}_{3}-$ & $\mathbf{N}-\mathrm{NH}_{4}{ }^{+}$ & $\mathbf{P}$ & $\mathbf{K}$ & $\mathrm{Ca}$ & Mg & $S$ & $\mathrm{Fe}$ & EC & [Ions] & Ionic force \\
\hline & \multicolumn{5}{|c|}{$\mathbf{m g ~ L ^ { - 1 }}$} & & & & Ds $\mathbf{m}^{-1}$ & \multicolumn{2}{|c|}{$\mathrm{mmol} \mathrm{L}^{-1}$} \\
\hline $\begin{array}{l}\text { Nutritive } \\
\text { solution }\end{array}$ & 174.0 & 24.0 & 39.0 & 183.0 & 142.0 & 38.0 & 52.0 & 32.0 & 1.7 & 26.9 & 21.9 \\
\hline
\end{tabular}

Source: Souza (2019) 
The experimental design used was completely randomized, in a $2 \times 6$ factorial scheme, that is, two levels for the nutrient solution factor (without and with added nutrient solution) and six levels for the time factor $(0,60,80,100,120$ and 140 days). Four repetitions were used, each consisting of 10 seedlings.

To evaluate the quality of seedlings, the following morphological parameters, relationships and quality indexes were considered in Equation (1): height of the aerial part $(\mathrm{H} ; \mathrm{cm})$; collection diameter (CD; mm); aerial part dry mass (SDM; g plant $\left.{ }^{-1}\right)$; dry root mass (DRM; g plant $\left.{ }^{-1}\right)$; total dry mass $\left(\mathrm{DMT}=\mathrm{SDM}+\mathrm{DRM}\right.$; g plant $\left.{ }^{-1}\right)$; dry mass of aerial part and dry mass of root (SDM/DRM); robustness index $\left(\mathrm{RI}=\mathrm{H} / \mathrm{CD} ; \mathrm{cm} \mathrm{mm}^{-1}\right)$; and Dickson's quality index (DQI). DQI was calculated according to TDM, H, CD, SDM and DRM, using the formula (DICKSON; LEAF; HOSNER, 1960).

$$
\mathrm{DQI}=\frac{\mathrm{TDM}(\mathrm{g})}{\frac{\mathrm{H}(\mathrm{cm})}{\operatorname{SCD}(\mathrm{mm})}+\frac{\operatorname{SDM}(\mathrm{g})}{\operatorname{RDM}(\mathrm{g})}}
$$

The data of $\mathrm{H}$ and $\mathrm{CD}$ were collected on the day of transplanting the seedlings into polypropylene pots (day 0), being reassessed at 60;80;100; 120 and 140 days after transplantation (DAT), at the end of the experiment. To obtain $\mathrm{H}$, a millimeter ruler was used, measuring from the base of the neck to the apical bud that gave rise to the last leaf. CD was measured with a precision digital caliper $(0.01 \mathrm{~mm})$.

To determine SDM and DRM, they were cut in half at the CD level, placed separately on kraft paper, dried in a forced ventilation oven at $65^{\circ} \mathrm{C}$ until constant mass (about 72 hours) and then weighed on an analytical scale at the Seed Analysis Laboratory of Embrapa Roraima.

Soon after, the seedlings were ground in a Willey mill and sampled to quantify macro levels, according to the methodologies described in Malavolta, Vitti and Oliveira (1997). Then, the levels of N, P, K, Ca, Mg and S of samples of dry plant material from the root and shoot were determined in each of the seedling growth periods (days after transplanting - DAT), using the methodology described by the Official Network of Soil and Plant Tissue Analysis Laboratories of RS and SC states - ROLAS (SOCIEDADE BRASILEIRA DE CIÊNCIAS DO SOLO, 2016). The content of each nutrient was calculated by multiplying the dry mass of each part of the plant by the concentration of each nutrient (BATAGLIA et al., 1983). The data referring to the evaluated characteristics that express the growth and nutritional status were subjected to analysis of variance and regression analysis for the time factor (periods), using the F test and, when significant, the Tukey test, the $5 \%$ probability using the Sisvar software (FERREIRA, 2011).

\section{Results and discussion}

At the end of the experiment (140 DAT), the survival rate of Khaya senegalensis seedlings was $100 \%$ for all treatments. All variables analyzed showed interaction $(p<0.05)$ between the factors Evaluation times (days) and with and without the addition of a nutrient solution (Table 2), indicating that the study of the interaction of factors is important to define which is the best time to apply nutrient solution so that they are robust and resistant to adverse conditions found in the field, presenting a higher survival rate and, consequently, needing a lower percentage of replanting (MELO et al., 2018).

The height $(\mathrm{H})$ and the diameter of the collection (CD) of the seedlings of Khaya senegalensis showed a direct relationship, and those that received addition of nutrient solution at 140 DAT, exhibited greater height $(91.75 \mathrm{~cm})$ and greater diameter $(17.12 \mathrm{~mm})$ in relation to the other times of the present research (Table 3).

In general, height is an important parameter, especially when there is a need to plant seedlings in areas colonized by spontaneous plants, a situation where the height of the species 
of interest needs to exercise greater competition for light (AGUILAR et al., 2020). The result given in the different evaluation periods, such as the 140 DAT period for variable $\mathrm{H}$ with gain, was approximately $18 \%$, which fact can be attributed to the addition of the nutrient solution to provide regular supply of nutrients. In addition to this, from the 100 DAT season onwards, it was necessary to add a nutrient solution to match the adequate availability of nutrients required by the seedlings of Khaya senegalensis to ensure greater growth and development (Table 3).

Table 3 - Height; collar diameter; shoot dry weight; root-system dry weight; total dry weight; robustness index; shoot dry weight and root-system dry weight the Dickson quality index, of seedlings of Khaya senegalensis without (WS) and with application of nutrient solution (NS) depending on the different seasons evaluated

Tabela 3 - Altura, diâmetro do coleto, massa seca da parte aérea, massa seca de raiz, massa seca total, índice de robustez, relação massa seca da parte aérea/raiz e índice de qualidade de Dickson de mudas de Khaya senegalensis sem (SS) e com (SN) aplicação de solução nutritiva em função das diferentes épocas avaliadas

\begin{tabular}{|c|c|c|c|c|c|c|c|c|c|c|c|c|c|c|c|c|}
\hline \multirow[b]{2}{*}{ Times } & \multicolumn{4}{|c|}{$\begin{array}{c}\mathbf{H} \\
(\mathbf{c m})\end{array}$} & \multicolumn{4}{|c|}{$\begin{array}{c}\mathrm{CD} \\
(\mathbf{m m})\end{array}$} & \multicolumn{4}{|c|}{$\begin{array}{c}\text { SDM } \\
\left(\text { g plant }^{-1}\right)\end{array}$} & \multicolumn{4}{|c|}{$\begin{array}{c}\text { DRM } \\
\left(\text { g plant }^{-1}\right)\end{array}$} \\
\hline & WS & & NS & & WS & & NS & & WS & & NS & & WS & & NS & \\
\hline $\mathbf{0}$ & 7.36 & fA & 7.69 & fA & 3.36 & $\mathrm{fA}$ & 3.41 & $\mathrm{fA}$ & 0.30 & $\mathrm{fA}$ & 0.30 & $\mathrm{fA}$ & 0.27 & $\mathrm{fA}$ & 0.29 & $\mathrm{fA}$ \\
\hline 60 & 24.01 & $\mathrm{eB}$ & 24.94 & eA & 6.72 & eA & 6.19 & $\mathrm{eB}$ & 3.84 & eA & 3.86 & eA & 1.15 & eA & 0.99 & $\mathrm{eB}$ \\
\hline 80 & 32.01 & $\mathrm{~dB}$ & 33.56 & $\mathrm{dA}$ & 8.59 & $\mathrm{~dB}$ & 9.44 & $\mathrm{dA}$ & 9.30 & $\mathrm{~dB}$ & 10.04 & $\mathrm{dA}$ & 1.96 & $\mathrm{~dB}$ & 2.84 & $\mathrm{dA}$ \\
\hline 100 & 44.63 & $c B$ & 46.10 & $\mathrm{cA}$ & 9.98 & $\mathrm{cB}$ & 12.54 & $\mathrm{cA}$ & 13.98 & $\mathrm{cB}$ & 15.44 & $\mathrm{cA}$ & 4.27 & $\mathrm{cB}$ & 4.86 & $\mathrm{cA}$ \\
\hline 120 & 47.58 & $\mathrm{bB}$ & 64.88 & $\mathrm{bA}$ & 11.12 & $\mathrm{bB}$ & 14.68 & $\mathrm{bA}$ & 21.91 & $\mathrm{bB}$ & 35.66 & $\mathrm{bA}$ & 5.76 & $\mathrm{bB}$ & 8.64 & $\mathrm{bA}$ \\
\hline 140 & 75.47 & $\mathrm{aB}$ & 91.75 & $\mathrm{aA}$ & 13.07 & $\mathrm{aB}$ & 17.12 & $\mathrm{aA}$ & 27.78 & $\mathrm{aB}$ & 52.31 & $\mathrm{aA}$ & 5.83 & $\mathrm{aB}$ & 12.56 & $\mathrm{aA}$ \\
\hline Average & 38.51 & B & 44.82 & A & 8.81 & B & 10.56 & $\mathrm{~A}$ & 12.85 & B & 19.60 & $\mathrm{~A}$ & 3.20 & $\mathrm{~B}$ & 5.03 & $\mathrm{~A}$ \\
\hline \multirow[t]{2}{*}{ CV\% } & \multicolumn{4}{|c|}{1.33} & \multicolumn{4}{|c|}{2.01} & \multicolumn{4}{|c|}{0.37} & \multicolumn{4}{|c|}{0.79} \\
\hline & \multicolumn{4}{|c|}{$\begin{array}{c}\text { TDM } \\
\left(\text { g plant }^{-1}\right)\end{array}$} & \multicolumn{4}{|c|}{ 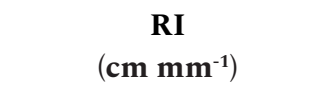 } & \multicolumn{4}{|c|}{$\begin{array}{c}\text { SDM/DRM } \\
\left(\text { gplant }^{-1}\right)\end{array}$} & \multicolumn{4}{|c|}{$\begin{array}{c}\text { DQI } \\
\text { Index }\end{array}$} \\
\hline Times & WS & \multicolumn{3}{|c|}{ NS } & WS & \multicolumn{3}{|c|}{ NS } & WS & \multicolumn{3}{|c|}{ NS } & WS & \multicolumn{3}{|c|}{ NS } \\
\hline $\mathbf{0}$ & 0.57 & $\mathrm{fA}$ & 0.59 & fA & 2.19 & $\mathrm{dA}$ & 2.25 & $\mathrm{eA}$ & 1.13 & $\mathrm{dA}$ & 1.05 & $\mathrm{eB}$ & 0.17 & $\mathrm{fA}$ & 0.18 & fA \\
\hline 60 & 4.99 & $\mathrm{eA}$ & 4.85 & $\mathrm{eB}$ & 3.58 & $\mathrm{cB}$ & 4.03 & $\mathrm{cA}$ & 3.35 & $\mathrm{cB}$ & 3.91 & $\mathrm{dA}$ & 0.72 & $\mathrm{eA}$ & 0.61 & $\mathrm{eB}$ \\
\hline 80 & 11.25 & $\mathrm{~dB}$ & 12.88 & $\mathrm{dA}$ & 3.73 & $\mathrm{cA}$ & 3.55 & $\mathrm{~dB}$ & 4.76 & $\mathrm{cA}$ & 3.53 & $\mathrm{cB}$ & 1.33 & $\mathrm{~dB}$ & 1.82 & $\mathrm{dA}$ \\
\hline 100 & 18.25 & $c B$ & 20.30 & $\mathrm{cA}$ & 4.47 & bA & 3.68 & $\mathrm{~dB}$ & 3.28 & $\mathrm{bA}$ & 3.17 & $\mathrm{bB}$ & 2.35 & $\mathrm{cB}$ & 2.96 & $\mathrm{cA}$ \\
\hline 120 & 27.67 & $\mathrm{bB}$ & 44.30 & $\mathrm{bA}$ & 4.28 & bA & 4.42 & $\mathrm{bA}$ & 3.80 & $\mathrm{aB}$ & 4.13 & $\mathrm{aA}$ & 3.42 & $\mathrm{bB}$ & 5.18 & $\mathrm{bA}$ \\
\hline 140 & 33.61 & $\mathrm{aB}$ & 64.87 & $\mathrm{aA}$ & 5.77 & $\mathrm{aA}$ & 5.36 & $\mathrm{aB}$ & 4.76 & $\mathrm{aA}$ & 4.17 & $\mathrm{aB}$ & 3.19 & $\mathrm{aB}$ & 6.81 & $\mathrm{aA}$ \\
\hline Average & 16.06 & B & 24.63 & A & 4.00 & A & 3.88 & B & 3.51 & A & 3.33 & B & 1.86 & B & 2.93 & A \\
\hline CV\% & \multicolumn{4}{|c|}{0.36} & \multicolumn{4}{|c|}{2.66} & \multicolumn{4}{|c|}{1.34} & \multicolumn{4}{|c|}{1.92} \\
\hline
\end{tabular}

Source: Authors (2019)

Where: In the column, means followed by different letters, lower case letters between treatments and capital letters between application or not of a nutrient solution, differ from each other by the Tukey test at 5\% probability. Height $(\mathrm{H}, \mathrm{cm})$, collar diameter $(\mathrm{CD}, \mathrm{mm})$, shoot dry mass $\left(\mathrm{SDM}, \mathrm{g} \mathrm{plant}^{-1}\right)$, root dry mass $\left(\mathrm{RDM}, \mathrm{g} \mathrm{plant}^{-1}\right)$, total dry mass (TDM, g plant $\left.{ }^{-1}\right)$, robustness index (RI), aerial part/root dry mass ratio (SDM/RDM) and Dickson quality index DQI), without nutrient solution (WS) and with nutrient solution (NS). 
At 140 (DAT), the seedlings of Khay a senegalensis with addition of nutrient solution showed a gain in DC of $24.1 \%$ in relation to the 140 DAT season without addition of nutrient solution (Table 3), justifying the importance of the need for particular studies among each application period for the genus Khaya. Thus, the results indicate that seedlings of Khaya senegalensis induce greater initial vigor, requiring greater absorption and accumulation of $\mathrm{K}$ (Figure $2 \mathrm{C}$ and $\mathrm{D}$ ), which promotes high water retention in plant tissues, greater cell turgor, resulting in superiority in the thickening of the stem, guaranteeing the setting and robustness of the plant in formation.

This last hypothesis reinforces results obtained in Tectonagrandis plants grown on substrates formulated with biosolids, in which Trazzi et al. (2014) found that the growth in diameter is directly related to the $\mathrm{K}$ level.

As well as the results obtained in this work, other current studies also confirm that mineral fertilizers induce superiority in height, as well as promote a larger diameter of the collection of several forest species (SOUZA; SMIDERLE; CHAGAS, 2018), this type of mineral fertilizer is being described as an effective input in the nursery phase, for inducing efficiency in the physiological processes that promote the rapid initial growth of plants (SOUZA et al., 2020a).

The results presented here allowed to answer part of the research problem, observing in the post-transplant evaluation of the seedlings of Khaya senegalensis that the growth was influenced by the different periods of evaluations with and without addition of nutrient solution, both for variables $\mathrm{H}$ and $\mathrm{CD}$ as for the robustness index (RI). The RI is the relationship between the height of the plant and the diameter of the collection and the lower its value, the more robust the seedling will be. For this index, it was observed that all periods of evaluations provided balance between height and diameter of the collection, with an average of $4.0 \mathrm{~cm} \mathrm{~mm}^{-1}$ and 3.8 $\mathrm{cm} \mathrm{mm} \mathrm{m}^{-1}$ with and without nutrient solution, respectively (Table 3).

In this sense, it is worth noting that RI is one of the most important morphological parameters to estimate the growth of seedlings in the field, although there is another index (DQI) that aggregates the main allometric parameters (RI and SDM/DRM) together, indicating, with greater precision, the quality of seedlings for final planting (REIS et al., 2016).

The results of the DQI of the present study with seedlings of Khaya senegalensis were similar to those obtained for seedlings of Khaya ivorensis, whose average values ranged from 3.8 to 5.4 (SOUZA et al., 2020b), however, values above the recommended by Lima Filho et al. (2019) whose value is below the minimum limit (0.30). According to Reis et al. (2016) the minimum DQI value is 0.30 being a good indicator of seedling quality, however, it is necessary to be cautious and consider this value in relation to each species and cultivation conditions. In the present work, this index was above this value from the 60 DAT season with and without nutrient solution, indicating sufficient quality for planting the seedlings in the field.

In addition to this, the dry mass of the aerial part, despite being a destructive method, must be considered once it indicates the rusticity of the seedlings (SOUZA et al., 2020a). The verification of the interactions and the main effects allowed to reach important answers of the present work and, consequently, consummate the research problem, verifying that the DRM, SDM, DRM/SDM ratio provided the production of seedlings with higher averages for the different times associated with the addition of nutrient solution (Table 3), showing that it is the most advantageous option for the production of Khaya senegalensis seedlings.

In practical terms, the superiority in the production of SDM exhibited by the seedlings of Khaya senegalensis with addition of nutrient solution from the 80 DAT season (Table 3), probably promoted the production and maintenance of root systems with greater root expansion, which propitiate the exploration of a larger soil area and, consequently, with greater efficiency of nutrient absorption (MELO et al., 2018).

The efficiency in root absorption tends to guarantee the necessary supply of nutrients for the aerial part, a fact evidenced by the $47 \%$ gain in the production of SDM (Table 3) with the addition of nutrient solution at 140 DAT in relation to the same period, but without the addition of nutritive solution, showing the relative investment of photoassimilates produced in 
photosynthesis for the production of biomass from these compartments of the plant.

For the SDM/RDM ratio, it was observed that the 140 DAT season with the addition of nutrient solution was less than the 140 DAT without the addition of associated nutrient solution (Table 3). The SDM/RDM relationship expresses the balance between the part that loses water (leaves) and the part that absorbs (roots), placing itself in a high degree of importance when implantation occurs in conditions of water deficiency, a context in which, the greater the result of the relationship, the greater the leaf area, which can lead to seedling growth imbalance and subsequent tipping, in addition to impairing the absorption of water and nutrients (MELO et al., 2018).

The verification of the interactions and the main effects allowed to obtain technical information on basic fertilization in nursery and, consequently, consummate the research problem, verifying that the RDM, SDM and the SDM/RDM ratio ensured a greater balance in the seedlings of Khaya senegalensis between different times with the addition of nutrient solution. Likewise, times and addition of nutrient solution provided seedlings with higher H, CD, RDM, SDM, TDM, however, by associating some of these variables (H, CD, RDM, SDM and TDM) in seedling quality indexes, the 140 DAT season with addition of nutrient solution proved to be the most advantageous option for the production of Khaya senegalensis seedlings.

Souza et al. (2020b), in their research proved that the addition of nutrient solution to the substrates used in the production of seedlings, guarantees the availability and efficient use of $\mathrm{N}$ by plants, $\mathrm{N}$ is an essential element to the components of the photosynthetic system, such as chlorophylls, carboxylase/oxygenase activity of ribulose 1.5 bisphosphate and phosphoenolpyruvate carboxylase, thus maintaining satisfactory rates of carbon assimilation, and consequently guaranteeing the production of photoassimilates that supply plant growth.

The percentage of $\mathrm{N}$ accumulation in the different organs of the Khaya senegalensis plants varied according to the seasons and application of nutrient solution, as shown in Figure $1 \mathrm{~A}$ and B. Seedlings of Khaya senegalensis accumulated $\mathrm{N}$ in a similar way between the organs, with small increases and synchronous according to the times after transplant. Additionally, African mahogany seedlings showed slightly higher nutrient accumulation in the roots after 80 DAT, to the detriment of the accumulation in the leaves. This response may be related to the purpose of increasing the root area for the absorption of nutrients, that is, at this moment, the preferential drains of consumption and storage of mineral and photoassimilated nutrients have become the aerial part, such as expanding stem and leaves, culminating in 140 DAT in the balance of $\mathrm{N}$ accumulation between these two organs (Figure $2 \mathrm{~A}$ and $\mathrm{B}$ ).

The highest accumulation of $\mathrm{N}$ in the aerial part was obtained with the addition of nutrient solution with a gain of $27.37 \%$ in relation to the addition of no nutrient solution at 140 DAT, this gain obtained may be related to the variables H, CD, SDM and RDM, since this nutrient promotes an increase in the chlorophyll content of the leaves, increasing the light absorption capacity, thus promoting an increase in the carbon fixation rate, and consequently an increase in the production of carbohydrates, which will serve as a substrate for the energy production and maintenance of plant growth rates (BASSI et al., 2018). It is worth noting that strategically the seedlings of Khaya senegalensis appear to have reached the period of greatest demand for $\mathrm{N}$ from the 100 DAT season.

As for the accumulation of $\mathrm{P}$ in the root system between seasons 0 and $100 \mathrm{DAT}$ with and without the addition of nutrient solution, there were similarities, however after 120 DAT, African mahogany seedlings with the addition of nutrient solution induced superiority in the accumulation of this nutrient in the aerial part (Figure $2 \mathrm{C}$ and $\mathrm{D}$ ).

The adequate content of nutrient $\mathrm{P}$ is essential for plant metabolism, allowing rapid and intense root growth (BERGHETTI et al., 2016), especially for its low mobility and functional importance, where it participates in the formation and integrity of cell membranes, in all trimmed of production and transfer of cellular energy that involves ATP, as well as in the metabolism of carbohydrates. 
Figure 2 - Mean values of accumulation of macronutrients in the root system and in the aerial part (y-axis) of seedlings of Khaya senegalensis without (WS) and with addition of nutrient solution (NS), depending on the evaluation time ( $x$-axis). (A and B: Nitrogen $(\mathrm{N})$; C and D: Phosphorus (P); E and F: Potassium (K); G and H: Calcium (Ca); I and J: Magnesium $(\mathrm{Mg})$; Sulfur $\mathrm{K}$ and $\mathrm{L}(\mathrm{S})$, respectively)

Figura 2 - Valores médios de acúmulo de macronutrientes no sistema radicular e parte aérea (eixo y) de mudas Khaya senegalensis sem (SS) e com adição de solução nutritiva (CS) em função das épocas de avaliação (eixo x). (A e B: Nitrogênio (N); C e D: Fósforo (P); E e F: Potássio (K); G e H: Cálcio (Ca); I e J: Magnésio (Mg); K e L Enxofre (S), respectivamente)

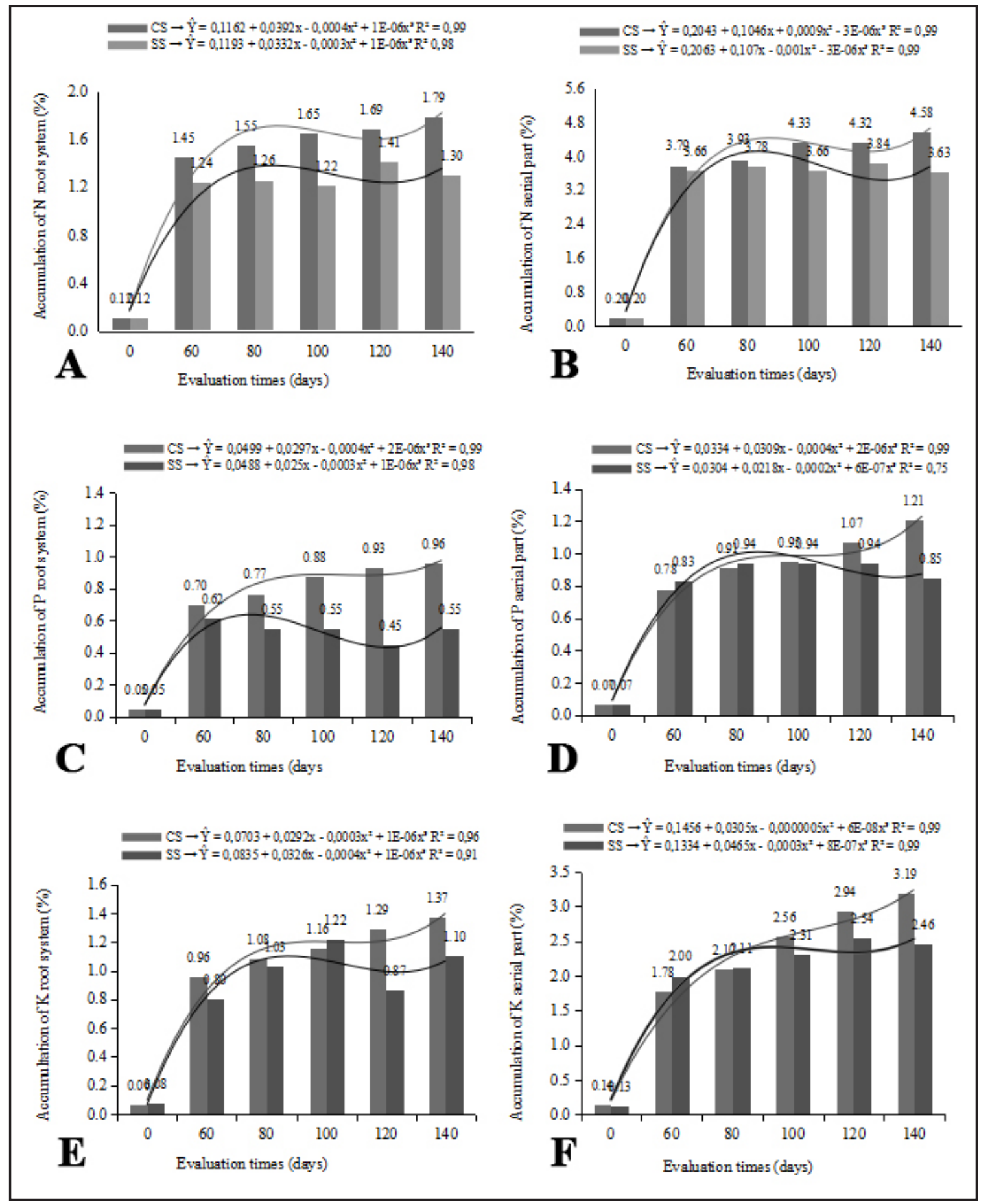


Figura 2 - Conclusão ...

Figura 2 - Conclusion ...

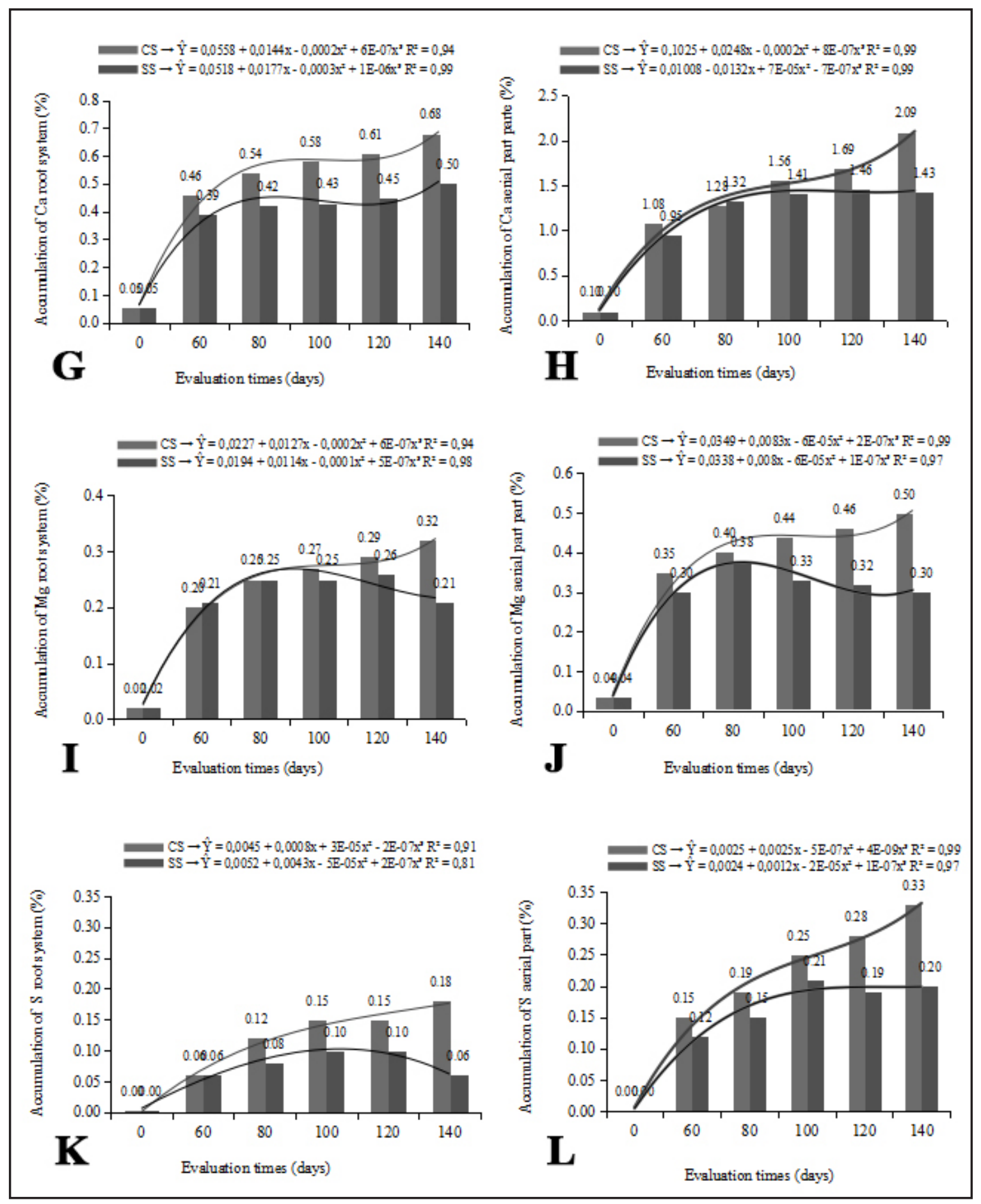

Source: Authors (2019)

In this sense, it is worth mentioning that the quality of the root system of Khaya senegalensis without the addition of a nutrient solution associated with the substrate, the roots were fragile, breaking easily when removing the substrate. It is probably related to the fact that calcium $(\mathrm{Ca})$ is found in an insufficient level in African mahogany seedlings, thus affecting the quality and the development of new roots (SOUZA et al., 2020b). Since Ca deficiency can 
show serious restrictions to the root development and growth, since this nutrient has limited internal redistribution, due to low mobility (MENEGATTI; SOUZA; BIANCHI, 2019).

Ca was the third most accumulated nutrient in the aerial part of the seedlings of Khaya senegalensis at $140 \mathrm{DAT}$ when added to the nutrient solution, with a maximum accumulation of $2.09 \mathrm{mg}$ plant $^{-1}$ (Figure $2 \mathrm{G}$ and H). Chu et al. (2019) in plants that exhibit a high rate of nutrient accumulation tend to produce phytomass in greater quantity. In the same way in this study, the greater accumulation of potassium (K) displayed in the aerial part of the seedlings of Khaya senegalensis, was highlighted with the use of the addition of nutrient solution in times 120 and 140 DAT when compared with those submitted without addition of nutrient solution, for both times (Figure $2 \mathrm{C}$ and $\mathrm{D}$ ).

According to Guo et al. (2019) $\mathrm{K}$ is an essential macronutrient for several plant physiological processes, among which are: enzyme activation, osmotic regulation, cell expansion, $\mathrm{pH}$ homeostasis, in addition to playing an essential role in the absorption of other elements, such as $\mathrm{N}$. The acquisition rates of $\mathrm{K}^{+} \mathrm{e} \mathrm{NO}_{3}^{-}$are often positively correlated, both for maintaining the balance of charges during the capture and accumulation of these two elements of opposite charges, and for the $\mathrm{K}^{+}$induced activation of the enzymes involved in the assimilation of nitrate (MENEGATTI; SOUZA; BIANCHI, 2019).

Thus, the higher $\mathrm{K}$ content indirectly stimulates the absorption and assimilation of $\mathrm{N}$, maximizing the use of this nutrient in the plant organ in which it is present in greater concentration, a fact that elucidates the response of the seedlings, regarding the superiority of the accumulation of $\mathrm{N}$ and $\mathrm{K}$ in the roots (Figure $2 \mathrm{C}$ and $\mathrm{D}$ ), concomitantly, associated with a greater accumulation of TDM in this organ.

In this sense, it can be evidenced that the accumulation of $\mathrm{Mg}$ in the seedlings of Khaya senegalensis (Figure $2 \mathrm{I}$ and $\mathrm{J}$ ) met the ideal range of nutritional requirement that is between 0.30 to $0.50 \%$ for African mahogany seedlings according to Souza et al. (2020b). The aforementioned authors show that with the adequate accumulation (0.2 to $0.4 \%$ ) of $\mathrm{Mg}$ in African mahogany seedlings, adequate photosynthetic rates can be obtained and, consequently, better adaptation of the plants during the field planting phase. However, there are few studies (ALVES et al., 2016; SMIDERLE et al., 2016; SOUZA et al., 2020b) on the supply of sulfur (S) in African mahogany seedlings in national and international literature.

The results obtained for the accumulation of $S$ in the aerial part of the seedlings varied from 0.12 to $0.33 \%$. Souza, Smiderle and Chagas (2018), establishes for forest species the adequate accumulation of $\mathrm{S}$, in general, is between 0.2 and $0.4 \%$. In the present study, the accumulation of S was within the range established by Souza et al. (2018), except in the witness and times $0 ; 60$ and 80 DAT with and without addition of nutrient solution (Figure $2 \mathrm{~K}$ and L). The $S$ applied in adequate doses can favor the best growth and development of plants by their participation in the conversion of non-protein nitrogen into protein (MENEGATTI; SOUZA; BIANCHI, 2019).

\section{Conclusions}

The maintenance of Khaya senegalensis seedlings with the use of a nutrient solution provides the best conditions for the use of macronutrients and allows seedlings to be able to be harvested in the field in 140 days after transplanting in a screened nursery in Roraima.

At 100 to 140 days after transplantation, there is a greater demand for macronutrients for the seedlings of Khaya senegalensis in a screened nursery in the northern Amazon.

The addition of solution is indicated for seedlings of Khaya senegalensis from 100 days after the transplantation in a screened nursery in the northern Amazon. 


\section{Acknowledgements}

We thank CNPq (National Council for Scientific and Technological Development), for the research productivity grant to the first and third corresponding author.

\section{Referências}

AGUILAR, M. V. M. et al. Produção de mudas de Albizialebbeck (L.) Benth sob diferentes formulações e doses de Osmocote. BIOFIX Scientific Journal, Curitiba, v. 5, n. 1, p. 153-160, 2020.

ALVES, M. S. et al. Crescimento e marcha de absorção de nutrientes em mudas de Khaya ivorensis. Acta Iguazu, Cascavel, v. 5, n. 2, p. 95-110, 2016.

AO, Y. et al. Combined effects of provenance and slow-release fertilizer on nursery and field performance of yellowhorn seedlings. Silva Fennica, Helsinki, v. 52, n. 2, p. 110-117, 2018.

AUCA, E. C. et al. Propagation of Brazil nut (Humb. y Bonpl) seedlings using seeds in minigreenhouses. Revista Agro@mbiente On-line, Boa Vista, v. 12, n. 4, p. 300-313, 2018.

BASSI, D. et al. Nitrogen supply influences photosynthesis establishment along the sugarcane leaf. Scientific Reports, New York, v. 8, n. 1, p. 2327-2340, 2018.

BATAGLIA, O. C. etal. Métodos de análise química de plantas. Campinas: Instituto Agronômico, 1983. 48 p. (Boletim Técnico, 78).

BERGHETTI, P. et al. Growth of Cordia trichotoma seedlings in different sizes of recipients and doses of fertilizer. African Journal of Agricultural Research, Nairobi, v. 11, n. 28, p. 2450-2455, 2016.

CABREIRA, G. V. et al. Fertilization and containers in the seedlings production and post-planting survival of Schizolobiumparahyba. Ciência Florestal, Santa Maria, v. 29, n. 4, p. 1644-1657, 2019.

CHU, X. et al. Responses of Taxuschinensis and Phoebe chekiangensis seedlings to controlledrelease fertilizer in various formulations and application rates.iForest - Biogeosciences and Forestry, Veneza, v. 12, n. 3, p. 254-261, 2019.

DICKSON, A.; LEAF, A. L.; HOSNER, J. F. Quality appraisal of white spruce and white pine seedling stock in nurseries. The Forest Chronicle, Cambridge, v. 36, n. 1, p. 10-13, 1960.

DIONISIO, L. F. S. et al. Seedling production of Bertholletiaexcelsa in response to seed origin and position inside fruit. Revista Brasileira de Ciências Agrárias, Recife, v. 14, n. 3, p. 5662, 2019.

FERREIRA, D. F. Sisvar: a computerstatisticalanalysis system. Ciência e Agrotecnologia, Lavras, v. 35, n. 6, p. 1039-1042, 2011.

GUO, J. et al. Growth, photosynthesis, and nutrient uptake in wheat are affected by differences in nitrogen levels and forms and potassium supply. Scientific Reports, New York, v. 9, n. 2, p. 1248, 2019.

LIMA FILHO, P. et al. Produção de mudas de Ceiba speciosa em diferentes volumes de tubetes utilizando o biossólido como substrato. Ciência Florestal, Santa Maria, v. 29, n. 1, p. 27-39, 2019.

MALAVOLTA, E.; VITTI, G. C.; OLIVEIRA, S. A. Avaliação do estado nutricional das plantas: princípios e aplicações. 2. ed. Piracicaba: Potafos, 1997. 319 p.

MARQUES, A. R. F. et al. Produção e qualidade de mudas de Psidiumcattleianumvar. CattleianumSabine (Myrtaceae) em diferentes substratos. Acta Biológica Catarinense, Joinville, v. 5, n. 1, p. 5-13, 2018. 
MELO, L. A. et al. Qualidade e crescimento inicial de mudas de Mimosa caesalpiniifoliaBenth. produzidas em diferentes volumes de recipientes. CiênciaFlorestal, Santa Maria, v. 28, n. 1, p. 47-55, 2018.

MENEGATTI, R. D.; SOUZA, A. G.; BIANCHI, V. J. Growth and nutrient accumulation in three peach rootstocks until the grafting stage. Comunicatascientiae, Bom Jesus, v. 10, n. 4, p.467-476, 2019.

REIS, S. M. et al. Desenvolvimento inicial e qualidade de mudas de CopaiferalangsdorffiiDesf. sob diferentes níveis de sombreamento. Ciência Florestal, Santa Maria, v. 26, n. 1, p. 11-20, 2016.

SOCIEDADE BRASILEIRA DE CIÊNCIAS DO SOLO. Comissão de Química e Fertilidade do Solo. Manual de adubação e de calagem para os Estados do Rio Grande do Sul e de Santa Catarina. 11. ed. Porto Alegre: Sociedade Brasileira de Ciência do Solo, Núcleo Regional Sul, 2016. $400 \mathrm{p}$.

SHI, W. et al. Fertilization and irrigation regimes influence on seedling attributes and field performance of PinustabuliformisCarr. International Journal of Forest Research, Miyazaki, v. 92, n. 1, p. 97-107, 2019.

SMIDERLE, O. J. et al. Growth and nutritional status and quality of Khaya senegalensis seedlings. Revista Ciências Agrárias, Belém, v. 59, n. 1, p. 47-53, 2016.

SMIDERLE, O. J. et al. Nutrient solution and substrates for 'cedrodoce' (Pochotafendleri) seedling production. Revista Brasileira de Engenharia Agrícola e Ambiental, Campina Grande, v. 21, n. 4, p. 227-231, 2017.

SMIDERLE, O. J. et al. Parâmetros de crescimento e curva de absorção de nutrientes de mudas de mogno africano com e sem solução nutritiva. Revista Brasileira de Agropecuária Sustentável, Viçosa, MG, v. 8, n. 4, p. 83-91, 2018.

SMIDERLE, O. J.; SOUZA, A. G. Production and quality of Cinnamomumzeylanicum Blume seedlings cultivated in nutrient solution. Revista Brasileira de Ciências Agrárias, Recife, v. 2, n. 2, p. 104-110, 2016.

SOUZA, A. G. et al. Controlled-Release Fertiliser and Substrates on Seedling Growth and Quality in Agonandrabrasiliensis in Roraima. Journal of Agricultural Studies, Turkia, v. 8, n. 3, p. 70-80, 2020a.

SOUZA, A. G. et al. Dry matter and nutrient accumulation in grafted peach seedlings in hydroponic system. Revista Brasileira de Fruticultura, Jaboticabal, v. 37, n. 2, p. 240-246, 2015.

SOUZA, A. G. et al. Growth, nutrition and efficiency in the transport, uptake and use of nutrients in african mahogany. Revista Ciência Agronômica, Fortaleza, v. 51, n. 2, p. e20196711, 2020b.

SOUZA, A. G.; SMIDERLE, O. J.; CHAGAS, E. A. Nutrition and accumulation of nutrients in Pochotafendleriseedlings. Revista Brasileira de Ciências Agrarias, Recife, v. 13, n. 3, p. 1-7, 2018.

TRAZZI, P. A. et al. Crescimento e nutrição de mudas de Tectonagrandis produzidas em substratos orgânicos. Scientia Forestalis, Piracicaba,v. 42, n. 101, p. 49-56, 2014. 